\title{
KEPENTINGAN ASING, AKTIVITAS INTERNASIONAL, DAN THIN CAPITALIZATION: PENGARUH TERHADAP AGRESIVITAS PAJAK DI INDONESIA
}

\author{
CHRISTINA NAINGGOLAN \\ DAHLIA SARI (dahlia-s@ui.ac.id)
}

Departemen Akuntansi, Fakultas Ekonomi dan Bisnis, Universitas Indonesia

\begin{abstract}
A B S T R A C T
This research investigates the impact of multinational company characteristics on tax aggressive in Indonesia. Those characteristics are identified by the existence of foreign interests, represented by significant foreign ownership and foreign director; international activities, represented by international related party transaction and multinational operation; and thin capitalization. This quantitative research uses sample of 150 IDX listed companies starting from 2011-2015. This research uses panel data for data regression. This study finds that the existence of foreign director and international related party transactions increase tax aggressiveness, while the significant foreign ownership decrease the tax aggressiveness.
\end{abstract}

Keyword : Tax Aggressive, International Tax Avoidance, Thin Capitalization.

Penelitian ini meneliti pengaruh karakteristik perusahaan multinasional terhadap agresivitas pajak di Indonesia. Karakteristik perusahaan multinasional terdiri dari kepentingan asing yang diwakili oleh adanya kepemilikan asing yang signifikan dan direksi asing; aktivitas internasional diwakili oleh transaksi ke pihak berelasi di luar negeri dan operasi di luar negeri (multinationality); serta thin capitalization. Penelitian ini mengambil sampel 150 perusahaan yang terdaftar di BEI selama tahun 2011-2015. Penelitian ini menggunakan data panel dalam pengolahan data. Hasil regresi data panel membuktikan bahwa keberadaan direksi asing dan transaksi ke pihak berelasi di luar negeri meningkatkan agresivitas pajak, sedangkan kepemilikan asing menurunkan agresivitas pajak.

Kata kunci : Agresivitas Pajak, Penghindaran Pajak Internasional, Thin Capitalization.

\section{PENDAHULUAN}

Perusahaan multinasional memiliki kesempatan yang lebih besar untuk melakukan penghindaran pajak dibanding perusahaan domestik karena perusahaan multinasional memiliki keunggulan dalam fleksibilitas geografis sehingga dapat memanfaatkan perbedaan tarif pajak antar negara melalui penggeseran penghasilan dan biaya (Rahayu, 2009). Egger et al. (2010) menyatakan bahwa perusahaan multinasional di Eropa cenderung melaporkan laba lebih besar di negara yang memiliki tarif pajak rendah sehingga pada akhirnya memiliki (Effective Tax Rate) ETR yang lebih rendah dibandingkan perusahaan domestik. Penelitian Dharmapala dan Riedel (2013) dengan sampel perusahaan multinasional di Eropa membuktikan terjadinya profit shifting dari perusahaan induk ke anak pe- rusahaan yang memiliki tarif pajak yang lebih rendah. Penelitian oleh Shevlin et al. (2012) di negara Cina juga menunjukkan bahwa profit shifting disinyalir terjadi ketika dalam satu grup, perusahaan berada dalam zona yang memiliki tarif yang berbeda.

Praktik penghindaran pajak internasional dilakukan dengan memindahkan laba ke negara yang memiliki tarif pajak lebih rendah sehingga secara grup utang pajak akan menjadi rendah. Pendirian anak perusahaan di luar negeri akan memberikan kesempatan kepada perusahaan untuk memanfaatkan perbedaan tarif pajak antar negara. Perusahaan yang mendirikan anak perusahaan di luar negeri juga berkesempatan untuk melakukan transaksi pihak berelasi dengan mekanisme transfer pricing sehingga secara bisnis perusahaan 
dapat lebih efisien. Transaksi dengan pihak berelasi ini kemudian berpotensi dimanfaatkan perusahaan untuk melakukan penghindaran pajak melalui pengenaaan harga transfer yang tidak arm's length price (ALP).

Skema pendanaan perusahaan melalui utang akan menjadi preferensi perusahaan untuk menurunkan beban pajak karena biaya utang dapat mengurangi penghasilan pajak. Modigliani dan Miller (1963) menganggap bahwa utang dapat dijadikan sebagai tax shield yang dapat meningkatkan nilai perusahaan. Perusahaan yang memiliki struktur utang yang jauh lebih besar dari modal disebut melakukan thin capitalization.

Kepentingan pihak asing pada perusahaan yang sering kali dikaitkan dengan karakteristik profitabilitas dan efisiensi yang tinggi (D'souza et al., 2001) menimbulkan pertanyaan apakah kepentingan asing berpengaruh terhadap agresivitas pajak. Kepentingan asing dapat dicirikan oleh struktur kepemilikan saham serta susunan direksi dan dewan komisaris yang didominasi oleh asing (Salihu et al., 2015).

Kemungkinan perbedaan pengaruh kepentingan asing terhadap penghindaran pajak terjadi karena di satu sisi perusahaan yang memiliki karakteristik kepemilikan asing cenderung untuk menerapkan tatakelola perusahaan yang lebih baik (Khanna dan Palepu, 2000), namun di sisi lain pihak asing tersebut memiliki kepentingan untuk mendapatkan laba sebesarbesarnya sehingga pajak yang dibayar akan diupayakan serendah mungkin. Hal ini dapat dicontohkan dari beberapa studi empiris terdahulu yang menemukan bahwa perusahaan multinasional Amerika Serikat membayar pajak yang rendah di host country meskipun laba yang dibukukan sangat tinggi (Grubert \& Mutti, 1991; Hines \& Rice, 1994; Kinney \& Lawrence, 2000).

Salihu et al. (2015) yang meneliti pengaruh kepentingan asing terhadap penghindaran pajak di negara berkembang dengan sampel perusahaan terbuka di Malaysia menemukan bahwa kepentingan asing yang diwakili oleh kepemilikan saham asing dan susunan dewan asing memiliki pengaruh positif terhadap praktik penghindaran pajak. Kusbandiyah dan Mat Norwani (2018) yang meneliti perusahaan manufaktur di Indonesia juga menemukan bahwa semakin besar kepemilikan asing, maka penghindaran pajak akan semakin tinggi. Sementara itu, penelitian mengenai pengaruh kepemilikan asing terhadap penghindaran pajak di Indonesia yang dilakukan oleh Rusyidi dan Martani (2014) tidak berhasil membuktikan bahwa kepemilikan asing memiliki pengaruh terhadap praktik penghindaran pajak.

Studi empiris yang dilakukan oleh Nadhir (2015) berhasil membuktikan bahwa kepentingan asing yang diwakili oleh kepemilikan asing berpengaruh positif terhadap praktik penghindaran pajak pada perusahaan manufaktur yang terdaftar di BEI. Namun, Nadhir (2015) tidak dapat membuktikan pengaruh direksi asing terhadap praktik penghindaran pajak. Studi kualitatif yang dilakukan oleh Rahayu (2013) menemukan bahwa transfer pricing, thin capitalization, pemanfaatan tax haven country, treaty shopping, dan controlled foreign corporation (CFC) merupakan skema yang paling sering digunakan oleh PMA untuk melakukan penghindaran pajak.

Penelitian mengenai pengaruh aktivitas internasional yang sering digunakan untuk menghindari pajak juga telah beberapa kali dilakukan di negara maju. Richardson dan Taylor (2012) menemukan bahwa praktik transfer pricing, income shifting, thin capitalization, pendirian anak perusahaan di luar negeri, dan pemanfaatan negara tax haven berpengaruh positif terhadap praktik penghindaran pajak pada perusahaan terbuka di Australia. Penelitian Ariffin (2013) dengan sampel perusahaan Malaysia juga membuktikan bahwa semakin tinggi aktivitas operasi di luar negeri yang dilakukan perusahaan, maka semakin tinggi penghindaran pajak yang dilakukan perusahaan tersebut. Rodriquez et al. (2019) yang meneliti perusahaan di Spanyol juga memeroleh hasil penelitian yang mendukung Ariffin (2013).

Berbeda dari penelitian terdahulu, penelitian ini menggunakan proksi agresivitas penghindaran pajak yang diajukan oleh Tang dan Firth (2012). Proksi agresivitas pajak dalam penelitian ini menggunakan 
Abnormal BTD yang merupakan representasi penghindaran pajak. Pengukuran Abnormal BTD ini dinilai akan lebih mencerminkan BTD yang mengandung penghindaran pajak.

Penelitian ini bertujuan untuk memeroleh gambaran komprehensif dari faktor-faktor yang memengaruhi praktik penghindaran agresif yang banyak dilakukan oleh perusahaan multinasional di Indonesia. Kontribusi penelitian ini adalah menggabungkan beberapa karakteristik perusahaan multinasional, yakni kepentingan asing (kepemilikan asing dan direksi asing), aktivitas internasional (transaksi dengan pihak berelasi dan multinasionalitas), dan thin capitalization dan menghubungkannya dengan penghindaran pajak.

Organisasi penulisan penelitian ini diawali dengan pendahuluan yang memaparkan latar belakang dan tujuan penelitian. Bagian berikutnya adalah tinjauan teoritis yang menjelaskan tentang agresivitas pajak, kepemilikan asing serta keterkaitan dengan teori agensi, yang akhirnya menjadi landasan untuk pembentukan hipotesis. Bagian ketiga menjelaskan tentang metode penelitian yang menjabarkan tentang model, operasionalisasi variabel, dan teknik pengolahan data. Bagian terakhir adalah hasil penelitian dan diakhiri dengan kesimpulan, keterbatasan, dan saran.

\section{TINJAUAN TEORITIS}

Penghindaran Pajak, Agresivitas Pajak, dan Penggelapan Pajak

Undang-undang Pajak Penghasilan (UU PPh) di Indonesia sampai sekarang belum memuat secara jelas definisi dari tax planning, tax aggressive, dan tax avoidance. Menurut Australian Tax Officer (ATO), perbedaan perencanaan pajak terletak pada intensi dari praktik tersebut dimana perencanaan pajak bertujuan untuk mengatur urusan perpajakan dengan cara yang efektif dan sesuai dengan hukum sementara penghindaran pajak adalah skema untuk melakukan penghindaran pajak dengan memanfaatkan kelemahan dari sistem perpajakan. Tindakan atau usaha untuk meminimalkan pembayaran pajak sering kali membuat perusahaan melakukan agresivitas pajak. Lanis dan Richardson (2011) mendefinisikan agresivitas pajak sebagai skema yang bertujuan semata-mata untuk menghindari pajak. Penggelapan pajak (tax evasion) adalah praktik penghindaran pajak yang sudah melanggar ketentuan perpajakan yang biasa dilakukan dengan cara tidak melaporkan penghasilan atau manipulasi yang disengaja.

Skema penghindaran pajak dapat dibedakan menjadi penghindaran pajak yang diperkenankan dan penghindaran pajak yang tidak diperkenankan dimana setiap negara memiliki interpretasi yang berbeda dalam mengidentifikasi penghindaran yang diperkenankan dan tidak diperkenankan. Rachel Tooma (2006) dalam Tax Notes International mengungkapkan beberapa skema yang termasuk dari agresivitas pajak menurut ATO, antara lain:

1. Melakukan transaksi yang tidak memiliki tujuan bisnis atau memiliki tujuan bisnis tetapi tidak signifikan. Dengan kata lain, transaksi tersebut dilakukan untuk menghindari pajak.

2. Berusaha untuk mendapatkan fasilitas pajak yang sebenarnya tidak berhak untuk didapat.

3. Membuat skema transaksi berputarputar sehingga pada akhirnya transaksi tersebut kembali lagi kepada pembuat skema transaksi (round-robin flow of funds).

4. Penggelembungan nilai aset dengan tujuan mendapatkan beban penyusutan yang besar sehingga deductible expense secara pajak menjadi tinggi.

5. Memanfaatkan entitas yang menerima penghasilan non taxable dengan tujuan untuk dikecualikan dari objek pajak.

6. Transaksi bisnis di negara berkategori tax haven.

\section{Kepemilikan Asing, Teori Agensi, dan Te- ori Cost and Benefit}

Pasal 1 ayat 8 UU Nomor 25 Tahun 2007 menyebutkan bahwa modal asing adalah modal yang dimiliki oleh negara asing, perseorangan warga negara asing, dan badan hukum di Indonesia yang sebagian atau seluruh modalnya dimiliki oleh pihak asing. Mengacu pada pasal tersebut, maka dapat disimpulkan bahwa kepemilikan sa- 
ham asing dapat dihitung dengan cara melihat proporsi jumlah saham asing terhadap jumlah saham seluruhnya. Beberapa penelitian terdahulu menunjukkan kepemilikan asing dalam perusahaan di negara berkembang dapat memberi keuntungan seperti adanya transfer teknologi dan penerapan tatakelola perusahaan yang baik (Kim et al., 2011). Selain memberikan keuntungan, kepemilikan asing juga berpotensi memberikan dampak negatif khususnya bagi negara yang memiliki tarif pajak tinggi.

Teori keagenan menyatakan bahwa akan terjadi informasi yang asimetris antara pemilik perusahaan dan dewan yang ditunjuk sebagai agen pengelola perusahaan. Hal ini karena agen selaku pihak yang mengelola perusahaan secara langsung memiliki informasi yang jauh lebih dalam dibanding pemilik. Masalah keagenan juga erat kaitannya dengan perbedaan kepentingan. Perbedaan kepentingan ini terjadi karena di satu sisi pemilik perusahaan menginginkan laba perusahaan yang tinggi untuk mendapatkan imbal hasil yang tinggi, namun di sisi lain manajemen berusaha untuk tidak memperoleh laba yang terlalu tinggi untuk menghindari pajak yang tinggi. Akibat dari masalah keagenan ini adalah manajemen akan menggunakan kemampuannya dalam mengelola laba fiskal dan akuntansi dengan memanfaatkan perbedaan peraturan dan tarif pajak antar negara.

Teori cost and benefit merupakan teori yang mengevaluasi suatu keputusan dengan mempertimbangkan konsekuensi yang akan timbul (Dreze dan Stern, 1987). Bagi pemilik perusahaan, keuntungan dari penghindaran pajak menandakan kesempatan untuk mendapatkan dividen dari perusahaan menjadi lebih besar. Keuntungan penghindaran pajak bagi manajemen adalah peningkatan insentif bonus akibat peningkatan laba perusahaan. Sementara itu, perilaku penghindaran pajak juga dapat menimbulkan cost bagi perusahaan. Risiko reputasi perusahaan merupakan salah satu cost yang dan mengancam eksistensi perusahaan, terutama jika publik memiliki awareness yang besar terhadap perusahaan tersebut (Salihu et al., 2014). Hanlon dan
Slemrod (2009) menemukan bahwa secara rata-rata harga saham perusahaan akan turun ketika perusahaan diberitakan terlibat dalam agresivitas pajak. Selain penurunan reputasi, cost yang dapat timbul dari aktivitas penghindaran pajak adalah kemungkinan penalti yang dikenakan oleh otoritas pajak (Salihu et al., 2014).

\section{PENGEMBANGAN HIPOTESIS Kepemilikan Asing Signifikan}

Strategi perusahaan dipengaruhi oleh kepentingan dari pemilik perusahaan dan salah satu kepentingan dari pemilik perusahaan multinasional adalah untuk menciptakan low-cost or efficiency seeking. Kepemilikan saham yang signifikan cenderung untuk bisa memengaruhi kebijakan perusahaan karena ada kepentingan yang cukup diperhitungkan. Rusydi dan Martani (2014) dalam studi empirisnya belum dapat menemukan hubungan antara kepemilikan asing dan perilaku agresivitas pajak pada perusahaan manufaktur yang terdaftar di BEI. Sementara itu, Salihu et al. (2015) meneliti bahwa kepemilikan asing signifikan pada perusahaan yang terdaftar di bursa Malaysia memiliki pengaruh positif terhadap tindakan pajak agresif dengan kemungkinan pemilik asing tersebut menggunakan skala internasional yang dimiliki untuk menghindari pajak baik di home country maupun di host country. Hasil penelitian Kusbandiyah dan Mat Norwani (2018) mendukung Salihu et al. (2015) bahwa semakin besar kepemilikan asing, maka penghindaran pajak akan semakin tinggi. Berdasarkan teori dan penelitian sebelumnya, hipotesis yang dapat dikembangkan adalah:

H1: Kepemilikan asing signifikan memiliki pengaruh positif terhadap agresivitas pajak.

\section{Susunan Direksi Asing}

Fama dan Jensen (1983) menyatakan bahwa komposisi dari direksi merupakan hal yang penting dalam mewujudkan pengawasan terhadap manajemen yang efektif. Richardson dan Taylor (2013) menjelaskan bahwa otoritas pajak menganggap manajemen risiko pajak dan perencanaan perpajakan adalah tanggung jawab dewan direksi. Hal 
ini menunjukan bahwa wakil asing yang ditempatkan di direksi bisa memberikan pengaruh yang cukup besar untuk ikut menggerakan jalannya perusahaan, termasuk dalam hal perilaku penghindaran perpajakan perusahaan. Direksi merupakan agen dari pemilik perusahaan yang bertanggungjawab untuk melindungi kepentingan pemilik melalui pencapaian target kinerja perusahaan. Oleh karena itu keberadaan direksi adalah untuk mewakili kepentingan pemilik sehingga keberadaan direksi asing tidak dapat dipisahkan oleh adanya pengaruh kepentingan dari pemililk asing. Salihu et al. (2015) menemukan bahwa proporsi dewan asing berpengaruh positif terhadap praktik penghindaran pajak di Malaysia. Berdasarkan teori dan penelitian sebelumnya, hipotesis yang dapat dikembangkan adalah:

H2: Jumlah direksi asing memiliki pengaruh positif terhadap agresivitas pajak.

\section{Transaksi ke Pihak Berelasi di Luar Negeri}

Adanya transaksi ke pihak berelasi menimbulkan keuntungan tersendiri bagi suatu perusahaan karena perusahaan dapat menetapkan harga transfer yang menguntungkan. Dalam akuntansi manajemen, transfer pricing merupakan harga yang dikenakan oleh satu subunit ke subunit lain di dalam suatu perusahaan yang sama (Horngren et al., 2012) dan bertujuan untuk meningkatkan efisensi dan sinergi antara perusahaan dan pemilik. Istilah transfer pricing sering dikonotasikan negatif karena pada praktiknya sering terdapat unsur manipulasi harga transfer sehingga penghasilan kena pajak menjadi lebih rendah.

Rahayu (2009) menyatakan bahwa transfer pricing sering dilakukan dengan merekayasa pembebanan harga atas transaksi antar perusahaan yang mempunyai hubungan istimewa dengan tujuan untuk mengurangi beban pajak terutang secara grup. Cross border transaction menjadi perhatian dalam isu transfer pricing karena sering kali transaksi ini bertujuan untuk memanfaatkan perbedaan tarif pajak sehingga harga transfer tidak menc- erminkan arm's length price. Richardson et al. (2013) menemukan bahwa praktik transfer pricing merupakan determinan praktik penghindaran pajak di Australia. Jacob (1996) menemukan bahwa perusahaan yang melakukan transaksi internasional antar pihak berelasi cenderung untuk membayar pajak lebih rendah. Berdasarkan teori dan penelitian sebelumnya, hipotesis yang dapat dikembangkan adalah:

H3: Transaksi ke pihak berelasi di luar negeri memiliki pengaruh positif terhadap agresivitas pajak.

\section{Multinasionalitas}

Perusahaan yang memiliki fleksibilitas geografis cenderung untuk melakukan praktik penghindaran pajak dengan memanfaatkan perbedaan tarif pajak antar negara. Dengan perusahaan beroperasi di lebih dari satu negara maka perusahaan dapat melakukan penghindaran pajak melalui pergeseran laba ke negara yang memiliki tarif pajak rendah dan manipulasi transaksi hubungan istimewa. Hasil penelitian yang dilakukan Rego (2003), Hanlon et al. (2005), Dyreng et al. (2008), dan Rodriguez et al. (2019) memperlihatkan bahwa sebuah perusahaan multinasional cenderung lebih memiliki kemampuan dan kesempatan untuk melakukan penghindaran pajak dibanding perusahaan yang hanya beroperasi di pasar domestik. Hasil yang sama juga diperoleh Kusbandiyah dan Mat Sarwani (2018) pada perusahaan di Indonesia.

Hal ini mengindikasikan bahwa perusahaan yang memiliki anak perusahaan di luar negeri memiliki kesempatan untuk melakukan perencanaan pajak antar anak perusahaan dengan tujuan memperkecil beban pajak grup secara global. Berdasarkan teori dan penelitian sebelumnya, hipotesis yang dapat dikembangkan adalah:

H4: Multinasionalitas pada perusahaan memiliki pengaruh positif terhadap agresivitas pajak

\section{Thin Capitalization}

Strategi perusahaan dalam memeroleh modal memiliki dampak yang signifikan terhadap laba yang dilaporkan untuk keperluan perpajakan. Dalam rangka 
meminimalisir pembayaran pajak, perusahaan akan cenderung menggunakan utang sebagai sumber pendanaan karena peraturan perpajakan memperbolehkan beban bunga, baik yang sudah dibayar maupun masih dalam bentuk hutang, sebagai beban yang dapat dikurangkan saat perhitungan laba fiskal. Dengan demikian, thin capitalization yang lebih tinggi akan membuat perusahaan lebih terindikasi melakukan penghindaran pajak. Dyreng et al. (2008) menyatakan bahwa perusahaan yang tergolong high leveraged akan memiliki tarif pajak yang lebih rendah. Berdasarkan teori dan penelitian sebelumnya, hipotesis yang dapat dikembangkan adalah:

H5: Thin capitalization memiliki pengaruh positif terhadap agresivitas pajak.

\section{METODE PENELITIAN \\ Sampel Penelitian}

Sampel penelitian ini adalah perusahaan yang terdaftar di BEI pada periode 20112015. Rentang waktu 5 tahun bertujuan untuk melihat tren dari perilaku perpajakan perusahaan. Metode pemilihan sampel pada penelitian ini adalah purposive sampling, yakni pemilihan sampel berdasarkan kriteria tertentu untuk menghindari bias dalam penelitian.

$$
\text { Periode pemilihan sampel }
$$
menggunakan periode 2011-2015 karena pada periode ini belum diberlakukan aturan pajak tentang thin capitalization (PMK Nomor 169 Tahun 2015) dan aturan pelaporan transaksi dengan para pihak yang mempunyai hubungan istimewa (PMK Nomor 213 Tahun 2016). Dengan membatasi sampel pada periode tersebut, maka pengaruh dari pemberlakuan kedua aturan belum tercermin pada sampel, sehigga seluruh sampel memiliki kondisi yang sama, yaitu belum dipengaruhi aturan thin capitalization dan aturan pelaporan transaksi dengan pihak yang mempunyai hubungan istimewa.

\section{Model Penelitian}

Model yang digunakan pada penelitian ini

$$
\begin{aligned}
\text { ATA }_{\mathrm{i}, \mathrm{t}}= & \alpha_{0}+\beta_{1} \text { Forgsig }_{\mathrm{i}, \mathrm{t}}+\beta_{2} \text { ForgBoard }_{\mathrm{i}, \mathrm{t}}+\beta_{3} \mathrm{TP}_{\mathrm{i}, \mathrm{t}} \\
& +\beta_{4} \operatorname{Multi}_{\mathrm{i}, \mathrm{t}}+\beta_{5} \operatorname{ThinCap}_{\mathrm{i}, \mathrm{t}}+\beta_{6} \operatorname{Size}_{\mathrm{i}, \mathrm{t}} \\
& +\beta_{7} \mathrm{ROA}_{\mathrm{i}, \mathrm{t}}+\beta_{8} \operatorname{Capint}_{\mathrm{i}, \mathrm{t}}+\varepsilon_{\mathrm{i}, \mathrm{t}}
\end{aligned}
$$

adalah sebagai berikut:

Keterangan:

i : Perusahaan 1-dst.

t : Tahun pelaporan keuangan.

ATA : Penghindaran pajak, Abnormal Book Tax Difference (Abnormal BTD), yaitu nilai absolut dari residual regresi total book tax difference (BTD).

Forgsig : Kepemilikan asing signifikan, yaitu variabel dummy dengan nilai "1" untuk perusahaan Indonesia yang memiliki kepemilikan asing signifikan dan " 0 " untuk perusahaan Indonesia yang tidak memiliki kepemilikan asing signifikan.

Forgboard: Proporsi anggota direksi, yaitu jumlah anggota dewan direksi asing dibagi total anggota dewan direksi.

TP : Transaksi ke pihak berelasi, jumlah penjualan dan pembelian dari pihak berelasi di luar negeri dibagi total ekuitas.

Multi : Multinasionalitas, yaitu variabel dummy dengan nilai "1" diberikan untuk perusahaan yang memiliki minimal satu anak perusahaan atau holding company yang berkedudukan di luar Indonesia dan nilai "0" untuk sebaliknya.

Thincap : Praktik thin capitalization, rasio total interest-bearing liabilities terhadap total ekuitas.

Size : Ukuran perusahaan, diukur dengan logaritma natural dari total aset.

ROA : Profitabilitas, diukur dengan menggunakan rumus laba sebelum pajak dibagi dengan total aset.

Capint : Intensitas penggunaan modal, diukur dengan rasio net of property, plant, and equipment terhadap total aset di periode sebelumnya.

e : Error

Variabel dependen pada penelitian ini adalah Abnormal BTD, yang merupakan proksi dari model yang dikembangkan oleh Tang dan Firth (2011). Model ini menghi- 
tung Abnormal BTD yang diperoleh dari nilai residual hasil regresi dari model BTD. Nilai residual model BTD merupakan BTD yang bersifat abnormal dan merupakan proksi variabel penghindaran pajak. Nilai residual ini diabsolutkan karena tanda negatif dan positif tidak memengaruhi posisi penghindaran pajak.

Selama ini pengukuran yang sering digunakan untuk mengukur penghindaran pajak adalah BTD, ETR, dan Current ETR. Tang dan Firth (2011) menyatakan bahwa BTD disebabkan oleh Normal BTD (yaitu BTD yang disebabkan oleh faktor-faktor yang wajar dan tidak mengandung penghindaran pajak), dan Abnormal BTD (yaitu BTD yang tidak dapat dijelaskan oleh Normal BTD). Normal BTD akan menjelaskan perubahan BTD yang diwakili dengan variabel perubahan property, plant, dan equipment (PPE), perubahan penjualan, dan rugi pajak. Abnormal BTD yaitu nilai residual hasil regresi Normal BTD terhadap BTD. Dari regresi model BTD ini, diperoleh residual (Abnormal BTD yang menjadi proksi penghindaran pajak) dari setiap perusahaan untuk setiap tahun penelitian. Model untuk memperoleh Abnormal BTD yang dikembangkan oleh Tang dan Firth (2011)

$$
\begin{aligned}
\mathrm{BTD}_{\mathrm{it}}= & \alpha_{0}+\alpha_{1} \Delta \mathrm{INV}_{\mathrm{it}}+\alpha_{2} \Delta \mathrm{REV}_{\mathrm{it}}+\alpha_{3} \mathrm{NOL}_{\mathrm{it}}+ \\
& \alpha_{4} \mathrm{TLU}_{\mathrm{it}}+\alpha_{5} \operatorname{PrevBTD}_{\mathrm{i}, \mathrm{t}}+\varepsilon_{\mathrm{it}}
\end{aligned}
$$

adalah sebagai berikut:

Keterangan:

$$
\begin{array}{ll}
\mathrm{i} & \text { : Perusahaan 1-dst. } \\
\mathrm{t} & \text { : Tahun pelaporan keuangan. } \\
\mathrm{BTD}_{\mathrm{it}} & \text { : Book tax difference pada perusa- } \\
& \text { han i di tahun } \mathrm{t} .
\end{array}
$$

$\Delta$ INVit : Perubahan investasi dalam gross aset tetap berwujud dan aset tetap tidak berwujud dari tahun $t$ -1 ke tahun $\mathrm{t}$.

$\triangle$ REVit : Perubahan pendapatan dari tahun $\mathrm{t}-1$ ke tahun $\mathrm{t}$.

NOLit : Jumlah kerugian fiskal perusahaan i pada tahun t.

TLUit : Jumlah kerugian yang telah dikompensasikan untuk perusahaan i pada tahun $\mathrm{t}$.

PrevBTD: Book tax difference pada perusahan i di tahun t-1.

eit : Error term yang merupakan Abnormal Book Tax Difference
(Abnormal BTD).

\section{Definisi Operasional Variabel Penelitian Variabel Independen}

Kepemilikan Asing Signifikan (FORGSIG)

Variabel kepemilikan asing signifikan pada penelitian ini mengambil definisi yang terdapat di PSAK 15, yakni presentase kepemilikan hak suara minimal 20\%. Variabel kepemilikan asing signifikan adalah variabel dummy dimana nilai "1" diberikan untuk perusahaan yang terdapat kepemilikan asing secara signifikan serta nilai "0" untuk sebaliknya. Pengukuran dengan variabel dummy ini disesuaikan dengan penelitian Salihu et al. (2015). Kepemilikan secara signifikan dapat lebih memengaruhi arah kebijakan perusahaaan dan karena pemilik asing memiliki kepentingan untuk memperoleh efisiensi pajak, maka diharapkan hasil penelitian ini akan menunjukan koefisien positif (+).

\section{Direksi Asing (FORGBOARD)}

Direktur diangkat dan dipilih oleh rapat umum pemegang saham sehingga direktur merupakan agen yang memiliki tanggung jawab fidusia dan bekerja untuk kepentingan pemilik perusahaan. Hal ini membuat keberadaan direksi asing adalah representasi kepentingan dari pemilik asing. Karena pemilik asing memiliki intensi untuk melakukan penghindaran pajak, maka direksi asing akan mengusahakan kebijakan yang mengarah pada agresivitas pajak untuk mengurangi beban pajak. Proksi direksi asing diukur dengan melihat proporsi direktur asing terhadap total direktur di suatu perusahaan Indonesia. Proksi ini disesuaikan dengan penelitian Salihu et al. (2015). Variabel ini diprediksi memiliki hubungan positif (+) dengan agresivitas pajak.

\section{Transaksi Pihak Berelasi (TP)}

Transaksi pihak berelasi diukur dengan jumlah penjualan dan pembelian dari pihak berelasi di luar negeri dibagi total ekuitas. Pengenaan harga transfer yang memiliki eksposur pajak adalah transaksi yang dilakukan antar negara (cross border transaction). Variabel ini diprediksi memiliki hubungan positif (+) dengan agresivitas pajak. 


\section{Multinasionalitas (Multi)}

Perusahaan yang memiliki operasi di luar negeri memiliki fleksibilitas yang lebih tinggi untuk melakukan profit shifting dibandingkan dengan perusahaan yang hanya beroperasi secara local. Selain itu, perusahaan yang memiliki operasi di luar negeri juga memiliki insentif lebih tinggi dalam melakukan penghindaran pajak karena adanya perbedaan tarif pajak antar negara. Variabel multinasionalitas diukur dengan proxy variabel dummy, dimana nilai "1" diberikan untuk perusahaan yang memiliki minimal satu anak perusahaan atau memiliki holding company di luar Indonesia dan nilai "0" diberikan untuk perusahaan Indonesia yang tidak memiliki anak perusahaan atau holding company di luar negeri. Pengukuran variabel dummy ini disesuaikan dengan penelitian Richardson dan Taylor (2012). Variabel ini diprediksi memiliki hubungan positif (+) dengan agresivitas pajak.

\section{Thin Capitalization (Thincap)}

Richardson dan Taylor (2013) mendefinisikan praktik thin capitalization sebagai strategi pendanaan perusahaan yang sangat mengandalkan utang dibanding ekuitas. Mengacu kepada cara pemerintah mengukur risiko thin capitalization, penelitian ini juga akan menggunakan rasio debt to equity (DER) sebagai tolak ukur risiko sebuah perusahaan melakukan agresivitas pajak melalui thin capitalization. Saldo utang yang digunakan untuk mengukur DER adalah saldo utang jangka panjang maupun jangka pendek yang dibebani bunga, sesuai dengan definisi pada peraturan perpajakan di Indonesia. Penelitian ini memprediksi koefisien (+) pada variabel thin capitalization karena perusahaan cenderung memanfaatkan beban bunga yang dapat mengurangi penghasilan kena pajak.

\section{Variabel Kontrol}

Penelitian ini menggunakan tiga variabel control yaitu ukuran perusahaan, ROA (Return on Assets), dan capital intensity. Ukuran perusahaan pada penelitian ini diukur dengan logaritma natural dari total aset suatu perusahaan. Pengukuran tersebut disesuaikan dengan penelitian Richardson dan Taylor (2012). Variabel ukuran perusahaan dimasukkan ke dalam model regresi sebagai variabel kontrol karena perusahaan dengan ukuran yang lebih besar cenderung memiliki utang pajak yang lebih rendah melalui perencanaan pajak yang dilakukan (Rego, 2003 dan Hanlon et al., 2005). Hasil penelitian ini diharapkan akan menghasilkan koefisien positif (+).

Variabel ROA (Return on Assets) diukur dengan laba sebelum pajak dibagi dengan total aset, sesuai dengan pengukuran dalam penelitian Richardson dan Taylor (2012). Arah korelasi dari variabel ini tidak dapat diprediksi sebab beberapa penelitian terdahulu tidak dapat memberikan hasil yang konsisten.

Variabel capital intensity diukur melalui rasio net of property, plant, and equipment terhadap total aset di periode sebelumnya, sesuai dengan penelitian Richardson dan Taylor (2012) dan diprediksi memiliki koefisien positif $(+)$ terhadap agresivitas pajak.

\section{ANALISIS DAN PEMBAHASAN \\ Populasi dan Sampel Penelitian}

Populasi yang digunakan dalam penelitian ini adalah seluruh perusahaan yang terdaftar di Bursa Efek Indonesia (BEI) pada tahun 2011-2015. Adapun kriteria pemilihan sampel adalah sebagai berikut.

1. Terdaftar di BEI sebelum 1 Januari 2011 sampai dengan 31 Desember 2015.

2. Menerbitkan laporan keuangan tahunan yang telah diaudit selama kurun waktu 2011-2015 dengan akhir periode laporan keuangan 31 Desember 2015.

3. Menggunakan mata uang rupiah pada laporan keuangan.

4. Bukan merupakan perusahaan yang bergerak di industri yang memiliki ketentuan perpajakan khusus, misalnya perusahaan pada industri keuangan, konstruksi, properti dan real estate, pertanian, dan pertambangan.

5. Data-data mengenai variabel-variabel yang akan diteliti tersedia dengan lengkap dalam laporan keuangan perusahaan dari tahun 2011 s.d 2015.

Berdasarkan kriteria di atas, terdapat 
150 perusahaan yang diambil menjadi sampel penelitian. Adapun proses pemilihan sampel dapat dijabarkan pada Tabel 1.

\section{Statistik Deskriptif}

Berdasarkan data statistik deskriptif pada Tabel 2 dapat dilihat bahwa $40.93 \%$ dari total sampel penelitian adalah perusahaan yang memiliki kepemilikan asing signifikan. Beberapa diantara perusahaan yang menjadi sampel penelitian tidak memiliki direksi asing, namun secara rata-rata, setiap perusahaan yang menjadi sampel memiliki proporsi direksi asing 11.96\%. Sekitar 50.53\% dari total sampel penelitian beroperasi secara internasional, baik dalam bentuk pendirian anak perusahaan maupun holding company di luar negeri. Secara rata -rata transaksi ke pihak berelasi di luar negeri yang dilakukan oleh sampel perusahan mengambil proporsi $10.34 \%$ dari total ekuitas. Sementara itu, posisi thin capitalization dari sampel perusahaan secara ratarata berada di $68 \%$ yang menandakan bahwa perusahaan yang menjadi sampel secara rata-rata masih mengandalkan ekuitas dalam pendanaan usahanya dibanding utang berbunga.

Total nilai transaksi penjualan dan pembelian ke pihak berelasi serta rata-rata

Tabel 1.

Pemilihan Sampel Penelitian

\begin{tabular}{lr}
\hline \multicolumn{1}{c}{ Kriteria: } & Jumlah \\
\hline Perusahaan yang terdaftar di Bursa Efek Indonesia & 533 \\
Dikurangi: & \\
$\quad$ Perusahaan dengan ketentuan peraturan perpajakan khusus & 310 \\
Perusahaan yang menggunakan denominasi selain Rupiah & 31 \\
Perusahaan yang tidak terdaftar dari Tahun 2011 s.d 2016 & 28 \\
Perusahaan dengan tahun fiskal selain 31 Desember & 2 \\
Perusahaan dengan ekuitas negatif & 5 \\
Perusahaan yang tidak memiliki data lengkap & 7 \\
Jumlah sampel perusahaan & 150 \\
Tahun penelitian & 5 \\
Jumlah sampel penelitian & 750 \\
\hline
\end{tabular}

Tabel 2.

Statistik Deskriptif

\begin{tabular}{lccccc}
\hline \multicolumn{1}{c}{ Variable } & $\mathbf{N}$ & Rata-Rata & Standar Deviasi & Min & Max \\
\hline Ata & 750 & 0.0196 & 0.0475 & 0 & 0.92 \\
Forgsig & 750 & 0.4093 & 0.4920 & 0 & 1 \\
Forgboard & 750 & 0.1196 & 0.2189 & 0 & 1 \\
Tp & 750 & 0.1034 & 0.5702 & 0 & 7.7386 \\
Multi & 750 & 0.5053 & 0.5003 & 0 & 1 \\
Thincap & 750 & 0.6811 & 0.8575 & 0 & 4.1635 \\
Size & 750 & 14.1968 & 1.7123 & 9.72 & 19.3200 \\
RoA & 750 & 0.0695 & 0.1164 & -0.48 & 1.4 \\
Capint & 750 & 0.5081 & 0.7866 & 0 & 16.1600 \\
\hline
\end{tabular}

Definisi variabel: ATA= nilai residual regresi dari total book tax difference (BTD); Forgsig= variabel dummy dengan nilai 1 jika terdapat kepemilikan saham asing signifikan dan 0 jika sebaliknya; Forgboard= proporsi direksi asing terhadap total direksi; $\mathrm{TP}=$ nilai penjualan ke pihak berelasi di luar negeri ditambah nilai pembelian dari pihak berelasi di luar negeri pada tahun t dibagi total net income pada tahun $\mathrm{t}$; Multi= variabel dummy dengan nilai 1 jika terdapat anak perusahaan di luar negeri atau memiliki parent di luar negeri dan 0 jika sebaliknya; Thincap= rasio utang jangka panjang dibagi ekuitas; Roa= proporsi laba sebelum pajak terhadap total aset; Size= logaritma natural dari total aset; Capint= rasio net of property, plant, and equipment terhadap total aset di periode sebelumnya; Invint= Rasio nilai persediaan dengan total aset di periode sebelumnya. 
rasio total transaksi terhadap ekuitas mengalami peningkatan dari tahun ke tahun seperti yang dapat dilihat pada pada tabel 3. Hal ini mengindikasikan bahwa intensitas untuk melakukan transaksi ke pihak berelasi semakin meningkat dari tahun ke tahun.

\section{Hasil Pengujian Hipotesis}

Hasil pengujian hipotesis 1 sampai dengan 5 dapat dilihat pada Tabel 4. Hasil pengujian atas hipotesis 1 menunjukkan bahwa kepemilikan asing signifikan memberikan pengaruh negatif signifikan terhadap praktik penghindaran pajak agresif, yang artinya semakin besar kepemilikan asing signifikan maka akan menurunkan penghindaran pajak. Hasil penelitian ini tidak sesuai dengan hipotesis 1 . Hasil ini juga berbeda dengan Salihu et al. (2015) dan Nadhir (2015) yang menyatakan bahwa kepemilikan asing signifikan berpengaruh positif terhadap praktik penghindaran pajak. Ada beberapa hal yang dapat menjelaskan hasil penelitian ini. Pertama, penghindaran pajak agresif memiliki cost berupa risiko hukum serta reputasi perusahaan dan hal ini dianggap memberikan efek lebih besar dibanding benefit yang didapat oleh praktik pajak agresif. Kedua, pemilik yang memiliki kepemilikan signifikan lebih cenderung bertujuan untuk mendapatkan long term value dari perusahaan sehingga pemilik akan berupaya untuk mendorong agen pengelola perusahaan untuk melaksanakan tatakelola perusahaan

Tabel 3.

Total Transaksi ke Pihak Berelasi di Luar Negeri (dalam Juta Rupiah)

\begin{tabular}{cccccc}
\hline Tahun & N & Penjualan & Pembelian & Total & $\begin{array}{c}\text { Rata-rata Total Transaksi } \\
\text { Terhadap Ekuitas }\end{array}$ \\
\hline 2011 & 150 & $6,302,483$ & $5,682,121$ & $11,984,604$ & 0.07835 \\
2012 & 150 & $6,643,614$ & $7,178,574$ & $13,822,188$ & 0.08016 \\
2013 & 150 & $7,764,394$ & $9,031,566$ & $16,795,960$ & 0.10524 \\
2014 & 150 & $15,100,000$ & $8,925,249$ & $24,025,249$ & 0.12269 \\
2015 & 150 & $19,200,000$ & $9,745,232$ & $28,945,232$ & 0.13072 \\
\hline
\end{tabular}

Tabel 4.

Hasil Regresi Hipotesis 1-5

\begin{tabular}{lccrr}
\hline \multicolumn{1}{c}{ Variabel } & Ekspektasi & Koefisien & $\mathbf{z}$ & \multicolumn{1}{c}{$\mathbf{P}>\mathbf{z}$} \\
\hline Forgsig & + & -0.0103 & -1.98 & $0.048^{* * *}$ \\
Forgboard & + & 0.0229 & 2.18 & $0.029^{* *}$ \\
TP & + & 0.0062 & 1.78 & $0.075^{* *}$ \\
Multi & + & 0.0026 & 0.51 & 0.613 \\
Thincap & + & -0.0001 & -0.02 & 0.982 \\
Size & $?$ & -0.0018 & -1.36 & 0.173 \\
RoA & $?$ & -0.1600 & -9.78 & $0.000^{* * *}$ \\
Capint & $?$ & 0.0025 & 1.25 & 0.210 \\
Intercept & & 0.0543 & 3.02 & $0.003^{* * *}$ \\
F Statistic & 0.0000 & & & \\
R-squared & 0.1527 & & & \\
\hline Definisi variabe & & &
\end{tabular}

Definisi variabel: ATA= nilai residual regresi dari total book tax difference (BTD); Forgsig= variabel dummy dengan nilai 1 jika terdapat kepemilikan saham asing signifikan dan 0 jika sebaliknya; Forgboard= proporsi direksi asing terhadap total direksi; $\mathrm{TP}=$ nilai penjualan ke pihak berelasi di luar negeri ditambah nilai pembelian dari pihak berelasi di luar negeri pada tahun t dibagi total net income pada tahun $\mathrm{t}$; Multi= variabel dummy dengan nilai 1 jika terdapat anak perusahaan di luar negeri atau memiliki parent di luar negeri dan 0 jika sebaliknya; Roa= proporsi laba sebelum pajak terhadap total aset; Size= logaritma natural dari total aset; Capint = rasio net of property, plant, and equipment terhadap total aset di periode sebelumnya; Invint= Rasio nilai persediaan dengan total aset di periode sebelumnya.

$*$ Signifikan di level $10 \% * *$ Signifikan di level $5 \% * *$ Signifikan di level $1 \%$ 
yang lebih baik. Tatakelola perusahaan yang lebih baik ini akan mendorong pemilik perusahaan untuk tidak melakukan penghindaran pajak agresif.

Hasil pengujian atas hipotesis 2 menunjukan bahwa kehadiran direksi asing memiliki pengaruh positif terhadap praktik penghindaran pajak agresif. Hasil penelitian ini sesuai dengan hipotesis 2 dan sejalan dengan Salihu et al. (2015). Perbedaan arah koefisien antara pemilik asing dan direksi asing terhadap praktik penghindaran pajak agresif ini menunjukan adanya conflict of interest antara pemilik sebagai principle dan direksi sebagai agen seperti yang dijelaskan pada teori keagenan. Direksi asing yang dibekali oleh pengetahuan dan kompetensi lebih akan mengupayakan untuk memperoleh short term value dari perusahaan sehingga direksi asing memiliki intensi lebih besar untuk terlibat dalam pajak agresif. Sementara itu, karena pemilik asing memiliki intensi untuk memperoleh long term value dari perusahaan, pemilik asing akan menghindari praktik pajak agresif agar perusahaan terhindar dari eksposur pajak.

Hasil pengujian atas hipotesis 3 menunjukkan bahwa transaksi ke pihak berelasi di luar negeri memiliki pengaruh positif terhadap agresivitas pajak. Hasil ini sesuai dengan hipotesis 3 dan membuktikan bahwa transaksi ke pihak berelasi di luar negeri mendorong perusahaan untuk melakukan penghindaran pajak. Hal ini sejalan dengan temuan Richardson dan Taylor (2012) yang menemukan bahwa skema transfer pricing merupakan salah satu determinan praktik penghindaran pajak terbesar.

Hasil pengujian atas hipotesis 4 tidak dapat menunjukkan bahwa karakteristik perusahaan yang beroperasi secara global memiliki pengaruh terhadap agresivitas pajak. Hasil penelitian ini tidak sesuai dengan hipotesis 4. Hasil penelitian ini tidak sesuai dengan penelitian Richardson dan Taylor (2012) yang membuktikan bahwa karakter multinasionalitas berpengaruh positif terhadap praktik penghindaran pajak. Argumen yang dapat menjelaskan hal ini adalah kemungkinan tujuan perusahaan Indonesia melakukan operasi di luar negeri adalah dalam rangka ekspansi dan untuk memeroleh sumber daya dengan cost lebih murah.

Hasil pengujian atas hipotesis 5 tidak dapat membuktikan bahwa praktik thin capitalization pada perusahaan memiliki pengaruh positif terhadap agresivitas pajak. Hasil ini tidak sesuai dengan hipotesis 5. Hasil pengujian tidak dapat membuktikan hasil penelitian Richardson dan Taylor (2012) yang menemukan bahwa praktik thin capitalization menjadi determinan dari praktik penghindaran pajak. Argumen yang dapat menjelaskan kondisi ini adalah perusahaan di Indonesia masih mengandalkan ekuitas untuk membiayai aset perusahaan, terlihat dari data statistik yang menunjukkan bahwa rasio utang berbunga terhadap modal di bawah 1. Oleh karena itu, dapat disimpulkan bahwa penggunaan utang di Indonesia belum mengarah ke praktik thin capitalization yang bertujuan untuk agresivitas pajak.

Variabel kontrol ROA terbukti memiliki pengaruh negatif signifikan terhadap praktik penghindaran pajak agresif. Hasil ini tidak sesuai dengan hasil penelitian Richardson dan Taylor (2012) yang menemukan pengaruh positif dari variabel terhadap praktik penghindaran pajak agresif. Argumen yang dapat menjelaskan kondisi ini adalah perusahaan yang melaporkan profitabilitas tinggi dan mengelola aset yang bernilai besar akan lebih terekspos untuk mendapatkan pajak yang tinggi, sehingga hal ini dapat berpengaruh negatif terhadap praktik penghindaran pajak agresif. Sementara itu, penelitian ini tidak dapat membuktikan bahwa variabel CAPINT dan SIZE memiliki pengaruh terhadap praktik penghindaran pajak agresif, berbeda dari penelitian Richardson dan Taylor (2012) yang dapat membuktikan pengaruh positif dari variabel ini terhadap praktik penghindaran pajak.

\section{SIMPULAN}

Penelitian ini bertujuan untuk melihat pengaruh karakteristik perusahaan multinasional yang terdiri dari kepentingan asing (kepemilikan asing signifikan dan direksi asing), aktivitas internasional, dan posisi thin capitalization terhadap agresivi- 
tas pajak. Kepemilikan asing signifikan terbukti memiliki pengaruh negatif terhadap praktik penghindaran pajak agresif. Hal ini mengindikasikan bahwa meskipun dimiliki oleh asing, pemilik tetap menginginkan long term value dari perusahaan sehingga akan berusaha untuk menerapkan tatakelola perusahaan yang baik dan meminimalisir terjadinya praktik penghindaran pajak agresif yang berpotensi memberikan eksposur hukum. Meskipun pemilik asing yang memiliki kepemilikan secara signifikan cenderung untuk meminimalisir praktik penghindaran pajak agresif, namun direksi asing yang memiliki kepentingan jangka pendek cenderung untuk melakukan penghindaran pajak agresif untuk mendapatkan laba yang diinginkan.

Transaksi ke pihak berelasi di luar negeri terbukti memiliki pengaruh positif terhadap agresivitas pajak. Hal ini mengindikasikan bahwa pengenaan harga transfer masih banyak yang tidak memenuhi prinsip arm's length sehingga mengindikasikan bahwa praktik ini digunakan untuk melakukan penghindaran pajak agresif. Karakteristik multinasionalitas atau adanya operasi di luar negeri tidak terbukti memiliki pengaruh terhadap agresivitas pajak. Hal ini kemungkinan karena tujuan melakukan operasi di luar negeri adalah untuk ekspansi bisnis. Kondisi perusahaan di Indonesia secara rata-rata masih mengandalkan ekuitas dalam pendanaan perusahaan sehingga penggunaan utang tidak berpengaruh terhadap agresivitas pajak. Hal ini dibuktikan oleh hasil penelitian yang menunjukan bahwa praktik thin capitalization tidak terbukti berpengaruh terhadap agresivitas pajak.

\section{KETERBATASAN DAN SARAN}

Penelitian ini memberikan implikasi berupa saran kepada pihak regulator, yaitu DJP (Direktorat Jendral Pajak) agar meningkatkan pengawasan terhadap perusahaan yang memiliki Dewan Direksi asing dan memperketat aturan atas transaksi kepada pihak berelasi. Keterbatasan penelitian ini adalah dalam pengukuran transfer pricing belum mencakup biaya jasa manajemen kepada pihak berelasi sehingga belum sepenuhnya mencerminkan volume transaksi ke pihak berelasi. Saran untuk penelitian ke depan agar memasukkan biaya jasa manajemen ke pihak berelasi agar dapat lebih mencerminkan seluruh transaksi ke pihak berelasi. Pada penelitian ini, kelemahan pengukuran thin capitalization adalah pengukuran transaksi utang berbunga tidak dibatasi pada pihak berelasi di luar negeri. Untuk saran penelitian berikutnya, pengukuran utang berbunga sebaiknya hanya ke pihak berelasi di luar negeri sehingga akan lebih mencerminkan usaha untuk menggunakan beban bunga sebagai alat untuk menghindari pajak melalui profit shifting ke pihak berelasi di luar negeri.

\section{DAFTAR PUSTAKA}

Ariffin, Z.Z. (2013). Tax planning of a company operating foreign activity in Malaysia. International Journal of Trade, Economics and Finance, 4(4), 209-212.

Dharmapala, D., \& Riedel, N. (2013). Earnings shocks and tax-motivated income-shifting: Evidence from European Multinationals. Journal of Public Economics, 97, 95-107.

Dreze J., \& Stern, N. (1987). The theory of cost benefit analysis. Handbook of public economics vol. II, 909-989.

Dyreng, S., Hanlon, M., \& Maydew, E. (2008). Long-run corporate tax avoidance. The Accounting Review, 83(1), 61-82.

D'souza, J., Megginson, W., \& Nash, R. (2001). Determinants of performance, improvements in privatized firms: the role of restructuring and corporate governance. Working paper, available on www.ssrn.com.

Egger, P., Egger, W., \& Winner, H. (2010). Saving taxes through foreign plant ownership. Journal of International Economics 81, 99-108.

Fama, E.F., \& Jensen, M.C. (1983). Separation of ownership and control. Journal of Law and Economics, 26, 301325.

Grubert, H., \& John, M. (1997). Do taxes influence where U.S. Corporations invest? U.S. Department of the Treasury. Mimeograph.

Hanlon, M., Mills, L., \& Slemrod, J. (2005). An empirical examination of corporate tax noncompliance. Working $\mathrm{Pa}$ per 1025. University of Michigan, University of Texas.

Hines, J.R., \& Rice E.M. (1994) Fiscal paradise: Foreign tax havens and American business. Journal of Economics 
vol 109, February 1994, 149-182.

Horngren, C.T., Datar, S.M., \& Foster, G. (2012). Cost of accounting: A managerial emphasis. Pearson.

Jacob, J. (1996). Taxes and transfer pricing: Income shifting and the volume of intrafirm transfers. Journal of Accounting Research Vol. 34(2) Autumn 1996, 301-312.

Khanna, Tarun, \& Krishna, P. (2000). Is group affiliation profitable in emerging markets? An analysis of diversified Indian Business Groups. Journal of Finance 55:867-891

Kim, J. B., Li, B., \& Zhang, L. (2011). Corporate tax avoidance and stock price crash risk: Firm level analysis. Journal of Financial Economics, 100(3), 639-662.

Kinney, M., \& Lawrence, J. (2000). An analysis of the relative US tax burden of US corporations having substantial foreign ownership. Natl Tax J. 53, 9-22.

Kusbandiyah, A., \& Mat Sarwani, N. (2018). Advances in Social Science, Education and Humanities Research, 231, 132135.

Lanis, R., \& Richardson, G. (2011). The effect of board of director composition on corporate tax aggressiveness. Journal of Accounting and Public Poli$c y, 30(1), 50-70$.

Nadhir, M.G. (2015). Pengaruh minat investor asing terhadap penghindaran pajak perusahaan manufaktur yang terdaftar di BEI 2011-2014 (Skripsi). Program S1 Paralel Akuntansi, Universitas Indonesia.

Rahayu, N. (2009). Praktik penghindaran pajak (tax avoidance) pada foreign direct investment yang berbentuk Subsidiary Company (PT.PMA) di Indonesia (Suatu kajian tentang kebijakan anti tax avoidance) (Disertasi). Program Pascasarjan. Universitas Indonesia.

Rahayu, N. (2010). Evaluasi atas praktik penghindaran pajak Penanaman Modal Asing. Jurnal Akuntansi dan Keu- angan Indonesia, 7(1), 61-78.

Richardson, G., \& Taylor, G. (2012). International corporate tax avoidance practices: Evidence from Australian Firms. The International Journal of Accounting, 47, 469-496

Richardson, G., \& Taylor, G. (2013) The determinants of thinly capitalized tax avoidance structures: Evidence from Australian Firms. Journal of International Accounting, Auditing and Taxation, 22, 12- 25

Richardson, G., Taylor, G., \& Lanis, R. (2013). The impact of board of director oversight characteristics on corporate tax aggressiveness: An empirical analysis. J. Account. Public Policy, 32, 68-88

Rodríguez, Elena, F., Roberto, G-F., \& Antonio, M.A. (2019). Influence of ownership structure on the determinants of effective tax rates of Spanish Companies. Sustainability 11.

Rusyidi, M. K., \& Martani, D. (2014). Pengaruh stuktur kepemilikan terhadap aggressive tax avoidance. $\mathrm{Pa}$ per diresentasikan pada acara Simposium Nasional Akuntansi 17.

Salihu, I.A., Sheikh, O., S.N., \& Annuar, H.A. (2014). Measures of corporate tax avoidance: empirical evidence from an emerging economy. Int. J. Bus. Soc. 14(3), 412-427.

Salihu, I., Annuar, H.A., \& Obid, S.N.S. (2015). Foreign investors' interests and corporate tax avoidance: Evidence from an emerging economy. Journal of Contemporary Accounting \& Economics 11, 138-147.

Shevlin, T., Tang, T.Y.H., \& Wilson, R.J. (2012). Domestic income shifting by Chinese Listed Firms. JATA American Accounting Association, 34(1), 1-29.

Tang, T., \& Firth, M. (2012). Earningss persistence and stock market reactions to the different information in booktax differences: Evidence from China. The International Journal of Account- 